\title{
Is the Aggregate Investor Reluctant to Realise Losses? Evidence from Taiwan
}

\section{Brad M. Barber}

Graduate School of Management, University of California, Davis, CA 95616, USA

E-mail:bmbarber@ucdavis.edu

\section{Yi-Tsung Lee}

Department of Accounting, National Chengchi University, Taipei, Taiwan

E-mail: actytl@nccu.edu.tw

\section{Yu-Jane Liu}

Department of Finance, Guanghua School, Peking University, China and Department of Finance National Chengchi University, Taipei, Taiwan

E-mail:finyjl@nccu.edu.tw

\section{Terrance Odean}

Haas School of Business, University of California, Berkeley, CA 94720, USA

E-mail: odean@berkeley.edu

\begin{abstract}
We ask whether the typical investor and the aggregate investor exhibit a bias known as the disposition effect, the tendency to sell investments that are held for a profit at a faster rate than investments held for a loss. We analyse all trading activity on the Taiwan Stock Exchange (TSE) for the five years ending in 1999. Using a dataset that contains all trades (over one billion) and the identity of every trader (nearly four million), we find that in aggregate, investors in Taiwan are about twice as likely to sell a stock if they are holding that stock for a gain rather than a loss. Eighty-four percent of all Taiwanese investors sell winners at a faster rate than losers. Individuals, corporations, and dealers are reluctant to realise losses, while mutual funds and foreigners, who together account for less than 5\% of all trades (by value), are not.
\end{abstract}

Keywords: individual investors; institutional investors; disposition effect; prospect theory.

JEL classification: $G 11$

We are grateful to the Taiwan Stock Exchange for providing the data used in this study. Michael Bowers provided phenomenal computing support, which made this project possible. Terrance Odean is grateful for the financial support of the National Science Foundation (Grant 0222107). 
Most clients, however, will not sell anything at a loss. They don't want to give up the hope of making money on a particular investment, or perhaps they want to get even before they get out.... Investors are also reluctant to accept and realise losses because the very act of doing so proves that their first judgment was wrong ... Investors who accept losses can no longer prattle to their loved ones, 'Honey, it's only a paper loss. Just wait. It will come back'.

Leroy Gross

The Art of Selling Intangibles: How to Make your Million(\$) by Investing Other People's Money

\section{Introduction}

Do the psychologically motivated trading biases that clearly affect some investors, affect enough investors so as to potentially influence asset prices? Are these biases restricted to a less sophisticated, less wealthy minority of investors, or are they the norm? In this paper, we ask whether the typical investor and the aggregate investor exhibit a bias known as the disposition effect, the tendency to sell investments that are held for a profit at a faster rate than investments held for a loss.

We answer this question in the context of the Taiwanese stock market. We analyse all trading activity on the Taiwan Stock Exchange (TSE) for the five years ending in 1999. Using a dataset that contains all trades (over one billion) and the identity of every trader (nearly four million), we are able to quantify the extent to which investors sell losers and winners (relative to the opportunities to sell each). We define a winner as a stock that has increased in value since its purchase and a loser as a stock that has declined in value since its purchase. In aggregate, investors in Taiwan are about twice as likely to sell a stock if they are holding that stock for a gain rather than a loss. Furthermore, $85 \%$ of all investors sell winners at a faster rate than losers.

In auxiliary analyses, we find the following empirical results:

1. We categorise investors into five broad categories: individuals, corporations, domestic mutual funds, foreigners, and dealers. Individuals, corporations, and dealers are reluctant to realise losses, while mutual funds and foreigners, who together account for less than $5 \%$ of all trades (by value), are not.

2. Short sellers are reluctant to realise losses. We analyse short sales and document similar patterns to those found for long positions; investors are reluctant to realise losses from short sales (i.e., buying to close a short position following price appreciation).

3. Both men and women are reluctant to realise losses. Consistent with Barber and Odean (2001), men trade more actively than women. However, the reluctance to realise losses is of similar magnitude for men and women.

4. The willingness to sell losers increases following strong market returns.

5. The disposition effect does not lead to momentum in Taiwanese stock returns.

Our results are consistent with a growing body of empirical work which documents that investors are reluctant to realise their losses. In contrast to prior studies, which analyse the decisions of a relatively small sample of investors or a relatively short time 
period, we analyse the complete transactions of all investors for a five-year period in the world's 12 th largest financial market. ${ }^{1}$

The plan of the paper is as follows. In section 2, we describe related research. In section 3, we describe the institutional details of the TSE, data, and methods. We present results in section 4, discuss implications in section 5, and make concluding remarks in section 6 .

\section{Related Research}

Shefrin and Statman (1985) propose that a combination of mental accounting (Thaler, 1985) and of utility functions similar to those described in Kahneman and Tversky's Prospect Theory (1979) leads investors to more readily sell stock investments held for a gain than those held for a loss. Due to mental accounting, investors focus on gains and losses from individual stock positions rather than focusing on portfolio returns or total wealth levels. Due to Prospect Theory-like utility functions, investors may prefer the risks of continuing to own a stock that they would otherwise have sold if that stock is currently held for a loss.

For some investors, the tendency to hold losers may be driven on a more basic level than probabilities of gains and losses. We live in a world in which most decisions are judged ex post and most people find it psychologically painful to acknowledge their mistakes. When a stock is sold for a loss, it becomes, irrevocably, an (ex post) mistake. A stock that one continues to hold for a loss, however, still might turn out to be a good (ex post) decision. Thus by continuing to hold onto their losers, investors postpone, and potentially avoid, admitting their mistakes.

Several empirical studies test this application of prospect theory to investments. Odean (1998) analyses the trades of 10,000 accounts at a discount brokerage between the years 1987 and 1993. He documents that winners are sold at roughly twice the rate of losers and shows that this phenomenon is not explained by taxes, rebalancing, or transaction costs. Barber and Odean (1999) confirm this result using data from the same discount broker, but different accounts, for the period 1991-1996. Using the same dataset, Dhar and Zhu (2006) document that the disposition effect is stronger for less sophisticated investors. Shapira and Venezia (2001) analyse the round-trip trades of about 4,000 Israeli investors during 1994; consistent with the predictions of prospect theory, losers are held two to three times longer than winners. Analysing trades of all Finnish investors for approximately two years ending in January 1997, Grinblatt and Keloharju (2001) conclude that Finnish investors are less likely to sell a stock held for a capital loss. Using logit regressions, they document this result in aggregate (weighting each trade equally) for five investor categories: households, non-financial corporations, financial and insurance companies, and government and non-profit institutions. ${ }^{2}$ Jackson (2004) reports that individual investors in Australia sell more actively after positive returns and buy less actively after negative returns; the first of these phenomena is consistent with

\footnotetext{
${ }^{1}$ The Economist Pocket World in Figures (London: Profile Books, 2002), p. 62.

${ }^{2}$ While Grinblatt and Keloharju (2001) also have data for foreign investors, they are unable to classify enough foreign sales as capital gains or losses to run their analysis. Due to their shorter time period and lower turnover rates, they are able to classify only $8 \%$ of all investors' sales while we classify $73 \%$.
} 
the disposition effect. Studies have also found evidence of the disposition effect in the exercise of company stock options (Heath et al., 1999), residential housing (Genesove and Mayer, 2001), and professional futures traders (Locke and Mann, 2001). Finally, Coval and Shumway (2005) report that market makers in Treasury Bond futures take on additional risk after experiencing recent losses - behaviour consistent with Prospect Theory and the disposition effect.

In work related to the disposition effect, Barber et al. (2006) find that investors are more likely to purchase a stock that they previously sold if the stock is currently trading at a lower price. They argue that an investor who sells and repurchases at a lower price feels good about these transactions, while an investor who repurchases at a higher price than he sold regrets having sold in the first place. To avoid this regret, investors avoid repurchasing for a higher price. Odean (1998) reports that investors are more likely to buy additional shares of a stock that has dropped in price since purchased than a stock that has appreciated. Again, a desire to avoid regret may explain this behaviour.

We contribute to understanding of the disposition effect by analysing all trades made on the TSE from 1995 to 1999 . We are able to document that the tendency to hold losses is exhibited by Taiwanese traders in aggregate as well as by the vast majority of these traders on an individual level. This extensive data set and (relatively) long time period enable us to provide compelling evidence that the both the typical and the aggregate investor are reluctant to realise losses.

\section{Background, Data and Methods}

\subsection{Taiwan market rules}

Before proceeding, it is useful to describe the Taiwan Stock Exchange (TSE). The TSE operates in a consolidated limit order book environment where only limit orders are accepted. During the regular trading session, from 9:00 a.m. to noon during our sample period, buy and sell orders can interact to determine the executed price subject to applicable automatching rules. Minimum tick sizes are set by the TSE and vary depending on the price of the security. Effective 2 November 1993, all securities listed on the TSE are traded by automatching through TSE's Fully Automated Securities Trading ('FAST') system. During our sample period, trades can be matched one to two times every 90 seconds throughout the trading day. Orders are executed in strict price and time priority. An order entered into the system at an earlier time must be executed in full before an order at the same price entered at a later time is executed. Although market orders are not permitted, traders can submit aggressive price-limit orders to obtain matching priority. During our study period, there is a daily price limit of $7 \%$ in each direction and a trade-by-trade intraday price limit of two ticks from the previous trade price.

The TSE caps commissions at $0.1425 \%$ of the value of a trade. Some brokers offer lower commissions for larger traders, though we are unable to document the prevalence of these price concessions. Taiwan also imposes a transaction tax on stock sales of $0.3 \%$. Capital gains (both realised and unrealised) are not taxed, while cash dividends are taxed at ordinary income tax rates for domestic investors and at $20 \%$ for foreign investors. Corporate income is taxed at a maximum rate of $25 \%$, while personal income is taxed at a maximum rate of $40 \%$. 
Table 1

Basic descriptive statistics for Taiwan Stock Exchange

The market index is a value-weighted index of all stocks traded on the TSE. Mean market cap is calculated as the sum of daily market caps divided by the number of trading days in the year. Turnover is calculated as half the value of buys and sells divided by market cap. Number of traders and number of trades are from the TSE dataset. Day trades are defined as purchases and sales of the same stock on the same day by one investor. Day trade percentage of all trades is based on value of trade; percentages based on number of trades are similar.

\begin{tabular}{lrcccccc}
\hline Year & $\begin{array}{c}\text { Return } \\
\%\end{array}$ & $\begin{array}{c}\text { Listed } \\
\text { firms }\end{array}$ & $\begin{array}{c}\text { Mean } \\
\text { market cap } \\
\text { (bil TW \$) }\end{array}$ & $\begin{array}{c}\text { Turnover } \\
\%\end{array}$ & $\begin{array}{c}\text { No. of } \\
\text { traders } \\
(000)\end{array}$ & $\begin{array}{c}\text { No. of } \\
\text { trades } \\
(000)\end{array}$ & $\begin{array}{c}\text { Day trade } \\
\text { as \% } \\
\text { of all trades }\end{array}$ \\
\hline 1995 & -27.4 & 347 & 5,250 & 195 & 1,169 & 120,115 & 20.6 \\
1996 & 33.9 & 382 & 6,125 & 214 & 1,320 & 149,197 & 17.3 \\
1997 & 18.2 & 404 & 9,571 & 393 & 2,173 & 310,926 & 24.8 \\
1998 & -21.6 & 437 & 9,620 & 310 & 2,816 & 291,876 & 25.6 \\
1999 & 31.6 & 462 & 10,095 & 292 & 2,934 & 321,926 & 21.8 \\
\hline $1995-99$ & 18.5 & & 8,132 & 294 & 3,971 & $1,194,040$ & 23.1 \\
\hline
\end{tabular}

\subsection{Trades data and descriptive statistics}

We have acquired the complete transaction history of all traders on the TSE from 1 January 1995, through 31 December 1999. The trade data include the date and time of the transaction, a stock identifier, order type (buy or sell - cash or margin), transaction price, number of shares, a broker code, and the identity of the trader. The trader code allows us to broadly categorise traders as individuals, corporations, dealers, foreign investors, and mutual funds. The majority of investors (by value and number) are individual investors. Corporations include Taiwan corporations and government-owned firms (e.g., in December 2000 the government-owned Post, Banking, and Insurance Services held over NT\$213 billion in Taiwanese stock). Dealers include Taiwanese financial institutions such as Fubon Securities, Pacific Securities, and Grand Cathay Securities. Foreign investors are primarily foreign banks, insurance companies, securities firms, and mutual funds. During our sample period, the largest foreign investors are Fidelity Investments, Scudder Kemper, and Schroder Investment Management. Mutual funds are domestic mutual funds, the largest being ABN-AMRO Asset Management, with NT\$82 billion invested in Taiwanese stocks in December 2000.

We present basic descriptive statistics on the market during the 1995 to 1999 period in Table 1. Several noteworthy points emerge. In contrast to the USA, which enjoyed an unprecedented bull market in the late 1990s, Taiwan experienced modest overall gains (see Figure 1). The main index for the Taiwan market (the TAIEX - a value-weighted index of all listed securities) enjoyed gains of over 30\% in 1996 and 1999 and losses of over 20\% in 1995 and 1998. Our sample period also includes the period of the Asian Financial crisis, which began in May 1997 with a massive sell-off of the Thai Bhat. This volatility provides a nice backdrop for the study of the disposition effect, since there are periods of rapid appreciation and depreciation.

Despite the return volatility in the Taiwan market, the overall value of the market has steadily grown. The number of firms listing in Taiwan grew at average annual rate of over 7\% between 1995 and 1999. The market value of the TSE nearly doubled from 


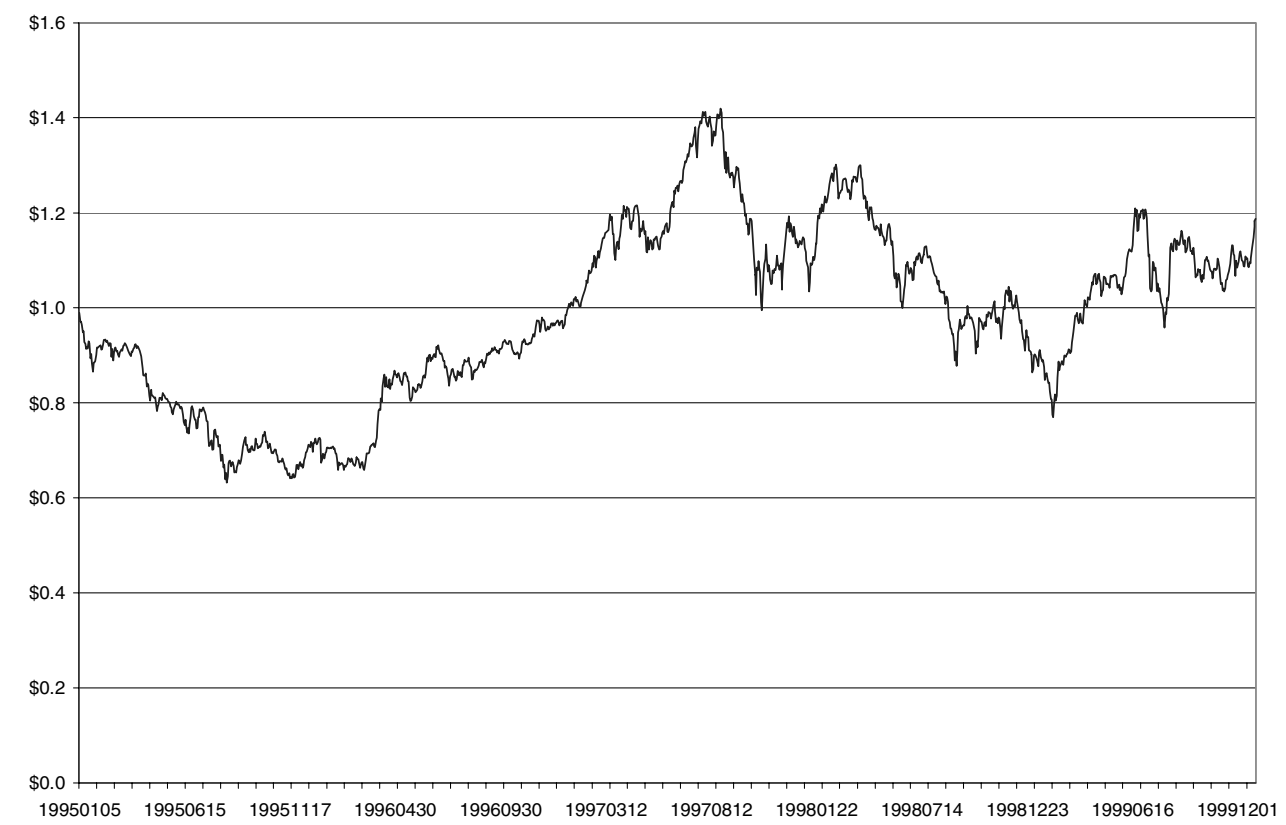

Fig. 1. Growth of \$1 invested in Taiwan Index on 31 December 1994.

1995 to 1999 - growing from NT\$ 5.2 trillion (US\$ 198 billion) in 1995 to over NT\$ 10 trillion (US\$ 313 billion) in $1999 .{ }^{3}$ At the end of 1999, the Taiwan market ranked as the 12th largest financial market in the world, though it was only slightly greater than $2 \%$ of the total US market.

Turnover in the TSE is remarkably high - averaging $292 \%$ annually during our sample period. ${ }^{4}$ In contrast, turnover on the New York Stock Exchange averaged 69\% during the same period. ${ }^{5}$ The number of traders and number of trades grew dramatically during our sample period. For the five-year period, we analyse more than one billion trades.

Day trading is also prevalent in Taiwan. We define day trading as the purchase and sale of the same stock on the same day by an investor. Over our sample period, day trading accounted for $23 \%$ of the total dollar value of trading volume. The majority of day trading $(64 \%)$ involves the purchase and sale of the same number of shares in a stock (i.e., most day trades yield no net change in ownership at the close of the day). ${ }^{6}$

Individual investors dominate the Taiwan market. According to the 2000 Taiwan Stock Exchange Factbook (Table 24), individual investors accounted for between 56 and 59\% of total stock ownership during our sample period. Taiwan corporations owned between 17 and $23 \%$ of all stocks, while foreigners owned between 7 and $9 \%$. At the end of 2000 ,

\footnotetext{
${ }^{3}$ The \$TW/\$US exchange rate reached a low of 24.5 and a high of 34.7 between January 1995 and December 1999.

${ }^{4}$ We calculate turnover as half the sum of buys and sells in each year divided by the average daily market cap for the year.

${ }^{5}$ NYSE Factbook 2000, p. 99.

${ }^{6}$ See Barber et al. (2005) for a comprehensive analysis of day trading in Taiwan. 
Table 2

Descriptive statistics by trader type

Data are from the Taiwan Stock Exchange. Seventeen traders are not classified, so the sum of trade values for Panels A through E do not equal the totals for all investors.

\begin{tabular}{|c|c|c|c|c|c|c|}
\hline \multirow[b]{2}{*}{ Years } & \multirow[b]{2}{*}{$\begin{array}{l}\text { No. of } \\
\text { traders }\end{array}$} & \multirow[b]{2}{*}{$\begin{array}{r}\text { Value of buys } \\
\text { (bil TW \$) }\end{array}$} & \multirow[b]{2}{*}{$\begin{array}{l}\text { Value of sells } \\
\text { (bil TW \$) }\end{array}$} & \multicolumn{2}{|c|}{ Average trades size (TW\$) } & \multirow{2}{*}{$\begin{array}{c}\% \text { of all } \\
\text { trades } \\
\text { (by value) }\end{array}$} \\
\hline & & & & $\begin{array}{l}\text { of buys } \\
\text { (TW \$) }\end{array}$ & $\begin{array}{c}\text { sells } \\
(\text { TW \$) }\end{array}$ & \\
\hline \multicolumn{7}{|c|}{ Panel A: Individual investors } \\
\hline 1995 & $1,161,923$ & 9,351 & 9,415 & 163,348 & 164,137 & 91.5 \\
\hline 1996 & $1,314,653$ & 11,613 & 11,619 & 165,517 & 165,956 & 88.4 \\
\hline 1997 & $2,164,728$ & 34,007 & 33,836 & 229,928 & 230,054 & 90.2 \\
\hline 1998 & $2,802,979$ & 26,597 & 26,532 & 192,829 & 193,596 & 89.1 \\
\hline 1999 & $2,920,320$ & 25,715 & 25,865 & 170,697 & 172,295 & 87.4 \\
\hline 1995-99 & $3,944,932$ & 107,283 & 107,267 & 190,256 & 190,995 & 89.2 \\
\hline
\end{tabular}

Panel B: Corporate investors

\begin{tabular}{lrrrrrr}
\hline 1995 & 6,723 & 367 & 337 & 322,301 & 310,009 & 3.4 \\
1996 & 4,744 & 603 & 633 & 346,035 & 347,476 & 4.7 \\
1997 & 7,654 & 1,623 & 1,705 & 462,120 & 467,239 & 4.4 \\
1998 & 11,860 & 1,425 & 1,498 & 387,712 & 381,958 & 4.9 \\
1999 & 12,271 & 1,232 & 1,409 & 344,527 & 348,809 & 4.5 \\
$1995-99$ & 24,358 & 5,250 & 5,582 & 384,771 & 384,454 & 4.5 \\
\hline
\end{tabular}

Panel C: Foreign investors

\begin{tabular}{lrrrrrr}
\hline 1995 & 206 & 167 & 116 & 270,937 & 256,082 & 1.4 \\
1996 & 424 & 302 & 247 & 303,636 & 277,612 & 2.1 \\
1997 & 703 & 647 & 642 & 426,726 & 371,005 & 1.7 \\
1998 & 939 & 553 & 517 & 371,698 & 318,292 & 1.8 \\
1999 & 1,281 & 972 & 642 & 340,493 & 294,918 & 2.7 \\
$1995-99$ & 1,570 & 2,641 & 2,163 & 353,560 & 314,805 & 2.0 \\
\hline
\end{tabular}

Panel D: Dealers

\begin{tabular}{lrrrrrr}
\hline 1995 & 46 & 103 & 112 & 349,918 & 361,299 & 1.0 \\
1996 & 52 & 156 & 157 & 344,087 & 368,529 & 1.2 \\
1997 & 59 & 511 & 513 & 512,592 & 506,696 & 1.4 \\
1998 & 72 & 428 & 444 & 415,888 & 402,614 & 1.5 \\
1999 & 75 & 533 & 507 & 414,875 & 387,717 & 1.8 \\
$1995-99$ & 83 & 1,732 & 1,732 & 426,463 & 416,701 & 1.4 \\
\hline
\end{tabular}

Panel E: Mutual funds

\begin{tabular}{lrrrrrr}
\hline 1995 & 105 & 271 & 280 & 357,295 & 328,619 & 2.7 \\
1996 & 107 & 460 & 478 & 369,950 & 329,589 & 3.6 \\
1997 & 139 & 832 & 925 & 546,644 & 466,383 & 2.3 \\
1998 & 185 & 771 & 776 & 448,398 & 366,548 & 2.6 \\
1999 & 214 & 989 & 1,023 & 407,987 & 326,144 & 3.4 \\
$1995-99$ & 289 & 3,323 & 3,482 & 433,411 & 365,017 & 2.8 \\
1995 & $1,169,003$ & 10,259 & 10,259 & 170,833 & 170,819 & 100.0
\end{tabular}


Table 2

Continued.

\begin{tabular}{|c|c|c|c|c|c|c|}
\hline \multirow[b]{2}{*}{ Years } & \multirow[b]{2}{*}{$\begin{array}{l}\text { No. of } \\
\text { traders }\end{array}$} & \multirow[b]{2}{*}{$\begin{array}{r}\text { Value of buys } \\
\text { (bil TW \$) }\end{array}$} & \multirow[b]{2}{*}{$\begin{array}{l}\text { Value of sells } \\
\text { (bil TW \$) }\end{array}$} & \multicolumn{2}{|c|}{ Average trades size (TW\$) } & \multirow{2}{*}{$\begin{array}{c}\% \text { of all } \\
\text { trades } \\
\text { (by value) }\end{array}$} \\
\hline & & & & $\begin{array}{l}\text { of buys } \\
\text { (TW \$) }\end{array}$ & $\begin{array}{c}\text { sells } \\
(\mathrm{TW} \$)\end{array}$ & \\
\hline \multicolumn{7}{|c|}{ Panel F: All investors } \\
\hline 1996 & $1,319,980$ & 13,134 & 13,134 & 176,066 & 176,055 & 100.0 \\
\hline 1997 & $2,173,287$ & 37,624 & 37,624 & 242,017 & 242,011 & 100.0 \\
\hline 1998 & $2,816,047$ & 29,799 & 29,799 & 204,189 & 204,187 & 100.0 \\
\hline 1999 & $2,934,176$ & 29,496 & 29,496 & 183,247 & 183,247 & 100.0 \\
\hline 1995-99 & $3,971,249$ & 120,312 & 120,312 & 201,524 & 201,519 & 100.0 \\
\hline
\end{tabular}

Taiwan's population reached 22.2 million; 6.8 million Taiwanese (31\%) had opened a brokerage account.

In Table 2, we present the total value of buys and sells for each investor group by year. As can be seen in the last column of the table, individual investors account for roughly $90 \%$ of all trading volume and place trades that are roughly half the size of those made by the four other groups (corporations, dealers, foreigners, and mutual funds). Each of the remaining groups accounts for less than $5 \%$ of total trading volume.

Obviously, individual investors are very active traders in Taiwan. Some back-ofthe-envelope calculations using data on the percentage ownership and trading for each investor group, we estimate that annual turnover for the individual investor group ranges between 308 and $630 \%$ annually from 1995 to $1999 .^{7}$

\subsection{Methods}

We wish to investigate whether investors are reluctant to realise loses. To test the null hypothesis that investors are equally likely to realise gains and losses, we calculate a daily hazard rate for the realisation of gains and losses. In general, on each day we break up an investor's portfolio into stocks held for gains and stocks held for losses. We then analyse the selling activity of the investor and calculate the proportion of his winners sold and the proportion of his losers sold.

Specifically, by going through each investor's trading records in chronological order, we construct a portfolio of individual stocks for which the purchase date and price are known. (See the appendix for the details of portfolio construction.) For stocks sold, the sales price for the stock is compared to its average purchase price to determine whether that stock was sold for a gain or a loss. Each stock that was in that portfolio at the beginning of that day but was not sold is considered to be a paper (unrealised) gain or loss. We compare the stock's daily high and low price to the average purchase price of the stock and categorise paper positions as gains, losses, or indeterminate (if the average purchase price falls between the daily high and low price). Our counts of the value and number of gains and losses realised are incremented daily (regardless of whether a sale

${ }^{7}$ For example, in 1995 the individual investor group accounted for $91.5 \%$ of all trades and $58.1 \%$ of stock ownership. Given annual market turnover of $195 \%$, this implies that turnover for individual investors was 308\%: $(91.5 / 58.1) \times 195$. 


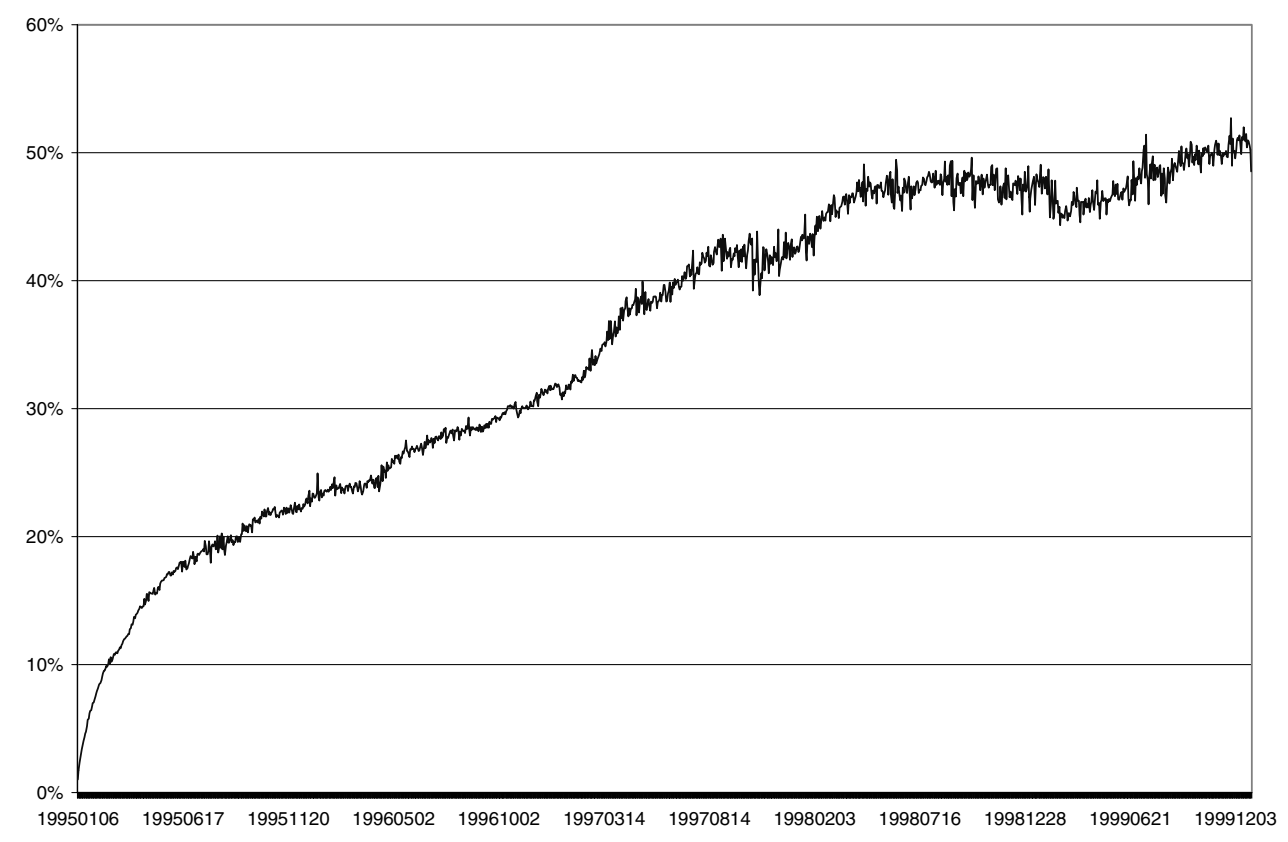

Fig. 2. Positions constructed from trades data as a percentage of total TSE market capitalisation

took place). Then, for each trader we calculate two ratios:

$$
\begin{aligned}
& \text { Proportion of gains realised }(\mathrm{PGR})=\frac{\text { Realised gains }}{\text { Realised gains }+ \text { Paper gains }} ; \\
& \text { Proportion of losses realised }(\mathrm{PLR})=\frac{\text { Realised losses }}{\text { Realised losses }+ \text { Paper losses }} .
\end{aligned}
$$

A large difference in the proportion of gains realised (PGR) and the proportion of losses realised (PLR) indicates that this investor preferred realising gains rather than losses (relative to his opportunity to realise each). ${ }^{8}$

Since we construct positions for each investor based on his trades, the constructed positions grow through our sample period. Because turnover on the TSE is quite high, the growth in positions occurs fairly quickly. By the end of 1995 constructed positions represent roughly $25 \%$ of total market capitalisation, while at the end of 1999 , constructed positions represent roughly half of total market capitalisation (see Figure 2). We are unable to construct positions for shares that are not traded. Though marketwide turnover is very high, nearly half of all shares in this market do not trade during our five year period.

\footnotetext{
${ }^{8}$ Our methodology follows that introduced in Odean (1998) with one important difference. Because of computing resource constraints, Odean evaluated an investor's paper gains and paper losses only for days on which the investor made a sale, while we do so every day. Thus our PGR and PLR calculations are equivalent to daily hazard rates at which winners and losers are sold. Direct comparisons of PGR and PLR across investors holding differing portfolio sizes can be made using our methodology, but not the earlier methodology.
} 
To establish statistical significance, we use two approaches. First, we calculate the difference between PGR and PLR for each investor. We calculate the mean difference across investors within a particular investor group (individuals, corporations, dealers, foreigners, or mutual funds). Statistical significance is based on the mean difference and the cross-sectional standard deviation of the difference.

Second, we separately sum realised gains, realised losses, paper gains, and paper losses across all investors and across each investor group on each calendar day. This allows us to calculate the difference between PGR and PLR on a particular day. We then calculate the mean difference across days for investors within a particular group (individuals, corporations, dealers, foreigners, or mutual funds). Statistical significance is based on the mean difference over time and the time-series standard deviation of the difference. The time-series standard deviations are calculated using the Newey-West correction for autocorrelation.

\section{Results}

\subsection{Cross-sectional results}

In Table 3, Panel A, we present the total value of paper gains, paper losses, realised gains, and realised losses for all investors and by investor type. Each field is summed across investors and over time. These values are used to calculate the proportion of gains realised (PGR) and the proportion of losses realised (PLR) in Table 3, Panel B. First, consider the results for all investors (in the last column of Table 3, Panel B). Gains are realised at a daily rate of $2.9 \%$, while losses are realised at a daily rate of $1.4 \%$ - less than half the rate for gains. In aggregate, investors are roughly twice as likely to sell a winner rather than a loser, providing strong support for the notion that the aggregate investor is reluctant to realise losses. ${ }^{9}$ To formally test whether investors are reluctant to realise losses, we separately calculate PGR and PLR for each investor and then average across investors. These results are presented in the last column of Table 3, Panel C. For the average investor, the proportion of gains realised is $9.4 \%$, while the proportion of losses realised is only $2.3 \%$. The difference in PGR and PLR (7.1\%) is reliably positive $(p<0.01)$. (The fact that these values are greater than those obtained when summing across investors and over time indicates that relative to the positions they hold, small investors tend to trade more actively than large investors.) Furthermore, 84\% of all investors realise gains at a faster rate than losses (i.e., PGR > PLR).

Our results by investor type indicate individuals, corporations, and dealers prefer to sell winners rather than losers. These results are similar regardless of whether we aggregate across investors and over time (Panel B) or average across investors (Panel C). In contrast, foreign investors and domestic mutual funds do not prefer to sell winners rather than losers. When we average across investors, we are unable to reject the null hypothesis that PGR equals PLR for foreigners, while domestic mutual funds display a modest preference for selling losers rather than winners $(p<0.05)$.

${ }^{9}$ PGR and PLR can be interpreted as daily turnover rates for gains and losses, respectively. When multiplied by the number of trading days in the year (on average, 279 in Taiwan), annual turnover is $809 \%$ for gains and $396 \%$ for losses. These figures are much higher than the turnover rates reported in Table 1 since we construct positions for only those who trade. As reported in Figure 2, we do not construct positions for roughly half of the market. These infrequent traders pull down marketwide turnover. 
Is the Aggregate Investor Reluctant to Realise Losses?

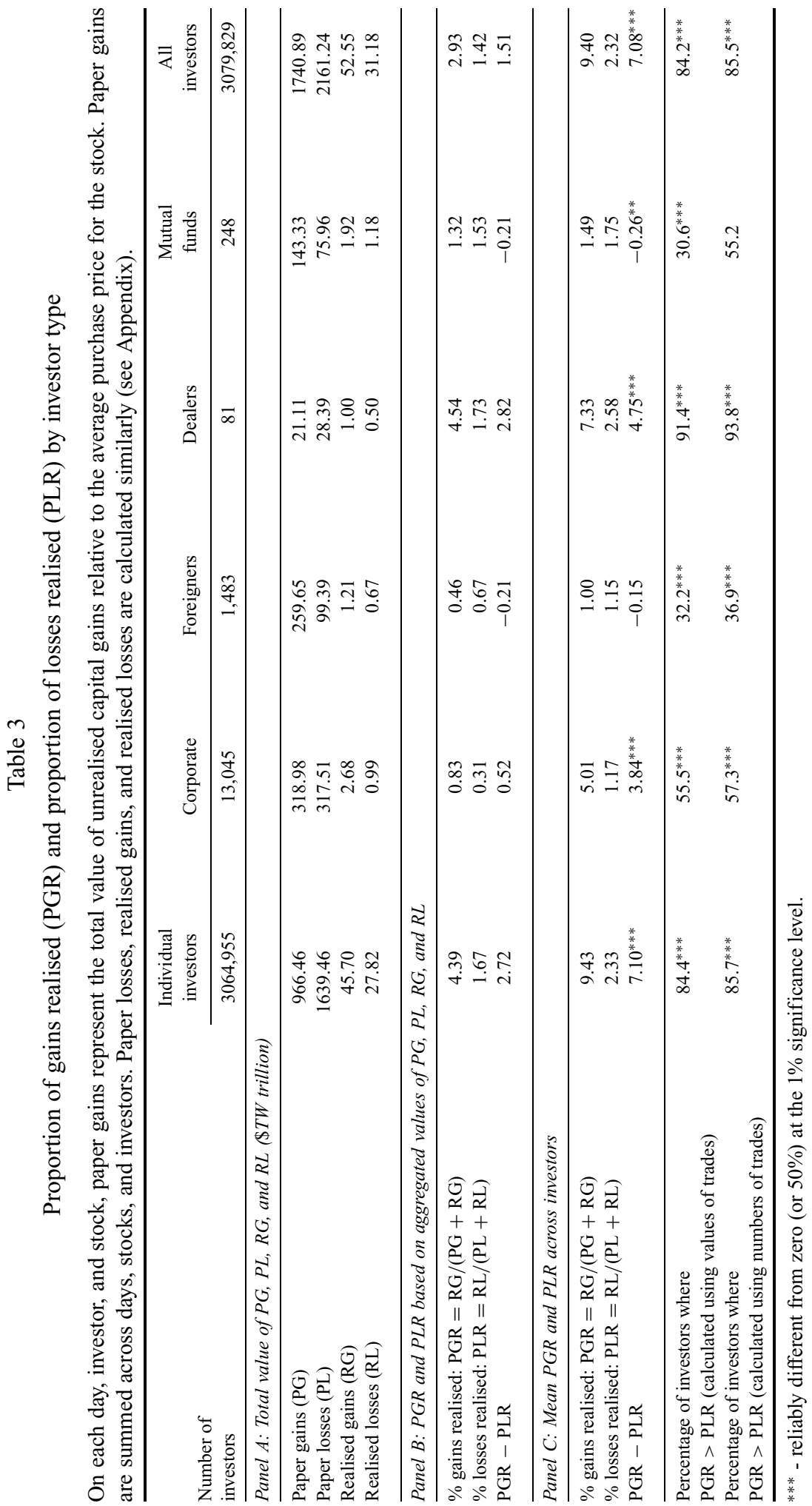




\subsection{Results by gender}

Though it would be interesting to explore the relation between the disposition effect and demographic characteristics, we have data on only one demographic variable - gender. Of the 3.1 million individual investors for whom we are able to calculate PGR and PLR, 1.7 million (55\%) are women and 1.4 million (45\%) are men. In contrast, $51 \%$ of the Taiwan population is male. Though it may seem unusual that there are more women than men who invest in the TSE market, we suspect this is largely a cultural phenomenon. In Taiwan, it is not unusual for women to buy and sell stocks after shopping at the market. This practice has become so prevalent in Taiwan that many brokerages market directly to this female clientele. In Taiwan, brokerage houses are lavish venues for trading stocks, which offer comfortable seating, tea, and VIP rooms for frequent traders.

In Table 4, we present the mean value of PGR, PLR, and the difference for men and women. Both men and women prefer to sell winners rather than losers. Though the difference between PGR and PLR is greater for men than women (7.19 and 7.02, respectively), the ratio of PGR to PLR is greater for women than men (4.7 and 3.6, respectively). Thus, though men realise gains at a faster rate than women (PGR is greater for men), they exhibit a somewhat lower preference for realising gains rather than losses (the ratio of PGR to PLR is less for men). The fact that men realise both gains and losses at a faster rate than women is consistent with the results in Barber and Odean (2001), which uses data from a large US discount broker to document that men trade more actively than women.

\subsection{Time-series results}

As described previously, we sum paper gains, paper losses, realised gains, and realised losses across investors for a particular day. We then calculate a daily value for the proportion of gains realised (PGR) and the proportion of losses realised (PLR). In Table 5, we present the results of our time-series analysis. Panel A contains the mean daily value of PGR; Panel B contains the mean daily value of PLR; Panel C contains the difference (PGR less PLR).

Consider first the results for all investors - presented in the last column of Table 5. PGR exceeds PLR in each year that we analyse and is reliably positive in each individual

Table 4

Mean PGR and PLR for women and men

For each day, investor, and stock, paper gains represent the total value of unrealised capital gains relative to the average purchase price for the stock. Paper gains are summed across days, stocks, and investors. Paper losses, realised gains, and realised losses are calculated similarly (see Appendix).

\begin{tabular}{lcc}
\hline & Men & Women \\
\cline { 2 - 3 } Number & 1408,737 & 1655,513 \\
\hline \% gains realised: PGR = RG/(PG + RG) & 10.00 & 8.95 \\
\% losses realised: PLR $=$ RL/(PL + RL) & 2.81 & 1.92 \\
PGR - PLR & $7.02^{* * *}$ & $7.19^{* * *}$ \\
Percentage of investors where PGR > PLR & $83^{* * *}$ & $85^{* * *}$ \\
\hline
\end{tabular}

*** - reliably different from zero (or $50 \%$ ) at the $1 \%$ significance level. 
Table 5

Daily proportion of gains realised (PGR) and proportion of losses realised (PLR) by investor type and year

On each day, the proportion of gains realised is the total value of realised gains divided by the sum of realised gains and paper gains. There is an analogous calculation for losses. The table presents the mean daily value of the proportion of gains realised and the proportion of losses realised. Standard deviations (in parentheses) are calculated using a Newey-West correction for serial dependence.

\begin{tabular}{cccccc}
\hline $\begin{array}{c}\text { Individual } \\
\text { investors }\end{array}$ & Corporations & Foreigners & Dealers & $\begin{array}{c}\text { Mutual } \\
\text { funds }\end{array}$ & $\begin{array}{c}\text { All } \\
\text { investors }\end{array}$ \\
\hline
\end{tabular}

Panel A: Mean of daily PGR

\begin{tabular}{lllllll}
\hline 1995 & 8.94 & 1.67 & 0.59 & 8.96 & 0.88 & 6.46 \\
1996 & 4.67 & 0.77 & 0.48 & 4.65 & 1.01 & 2.95 \\
1997 & 4.40 & 0.80 & 0.60 & 5.21 & 1.27 & 3.01 \\
1998 & 4.06 & 0.69 & 0.50 & 4.65 & 1.26 & 2.67 \\
1999 & 3.64 & 0.90 & 0.39 & 3.83 & 1.57 & 2.51 \\
$1995-99$ & 5.06 & 0.95 & 0.51 & 5.39 & 1.20 & 3.45
\end{tabular}

Panel B: Mean of daily PLR

\begin{tabular}{lllllll}
\hline 1995 & 1.92 & 0.40 & 0.47 & 2.08 & 0.88 & 1.65 \\
1996 & 1.89 & 0.33 & 0.61 & 1.68 & 1.01 & 1.61 \\
1997 & 2.80 & 0.64 & 0.95 & 3.33 & 1.27 & 2.52 \\
1998 & 1.40 & 0.32 & 0.68 & 1.49 & 1.26 & 1.22 \\
1999 & 1.42 & 0.23 & 0.67 & 1.51 & 1.57 & 1.19 \\
$1995-99$ & 1.90 & 0.39 & 0.68 & 2.03 & 1.20 & 1.65
\end{tabular}

Panel C: Mean of difference (PGR-PLR)

\begin{tabular}{lcccccc}
\hline 1995 & $7.02^{* *}$ & $1.27^{* *}$ & 0.11 & $6.88^{* *}$ & 0.12 & $4.81^{* *}$ \\
& $(0.85)$ & $(0.13)$ & $(0.07)$ & $(1.33)$ & $(0.10)$ & $(0.57)$ \\
1996 & $2.78^{* *}$ & $0.44^{* *}$ & $-0.13^{* *}$ & $2.98^{* *}$ & $-0.14^{*}$ & $1.34^{* *}$ \\
& $(0.48)$ & $(0.08)$ & $(0.04)$ & $(0.40)$ & $(0.06)$ & $(0.29)$ \\
1997 & $1.60^{* *}$ & $0.15^{* *}$ & $-0.35^{* *}$ & $1.88^{* *}$ & $-0.91^{* *}$ & $0.49^{* *}$ \\
& $(0.36)$ & $(0.07)$ & $(0.06)$ & $(0.62)$ & $(0.19)$ & $(0.30)$ \\
1998 & $2.66^{* *}$ & $0.37^{* *}$ & $-0.19^{* *}$ & $3.16^{* *}$ & $-0.43^{* *}$ & $1.45^{* *}$ \\
& $(0.25)$ & $(0.06)$ & $(0.03)$ & $(0.25)$ & $(0.09)$ & $(0.19)$ \\
1999 & $2.23^{* *}$ & $0.67^{* *}$ & $-0.28^{* *}$ & $2.32^{* *}$ & $-0.85^{* *}$ & $1.32^{* *}$ \\
& $(0.34)$ & $(0.08)$ & $(0.02)$ & $(0.48)$ & $(0.15)$ & $(0.24)$ \\
$1995-99$ & $3.17^{* *}$ & $0.56^{* *}$ & $-0.17^{* *}$ & $3.36^{* *}$ & $-0.45^{* *}$ & $1.81^{* *}$ \\
& $(0.36)$ & $(0.07)$ & $(0.03)$ & $(0.40)$ & $(0.08)$ & $(0.26)$ \\
\hline
\end{tabular}

**, ${ }^{*}$ - reliably different from zero at the 1 and $5 \%$ significance level, respectively.

year with the exception of $1997(t=1.63)$. Furthermore, in aggregate, investors realise gains at a greater rate than losses on $87 \%$ of days that we analyse (PGR exceeds PLR on 1,214 days out of 1,395 total trading days). Again, we find strong support that the aggregate investor is reluctant to realise losses.

The time-series results by investor type are generally consistent with those reported in Table 3. Individuals, corporations, and dealers prefer to sell winners rather than losers. 
These results are quite robust across years. In contrast, with the exception of 1995 the first year in our analysis, foreign investors and domestic mutual funds prefer to sell losers rather than winners.

\subsection{Short sales}

The analysis of short sales provides a natural test of the robustness of our results. If investors are reluctant to realise losses, they should prefer to cover short positions when stocks have declined in value and maintain short positions when stocks increase in value. During our sample period, only individual investors and corporations were allowed to short stocks; foreigners, domestic mutual funds, and dealers were precluded from doing so. We are able to identify approximately 330,000 individuals and 1,100 corporations that sold short during our sample period.

A short position is classified as a paper gain if the stock's price is below the average (short) sales price and a paper loss if the stock's price is above the average (short) sales price. As for long positions, we sum paper gains, paper losses, realised gains, and realised losses across investors for a particular day. We then calculate a daily value for the proportion of gains realised (PGR) and the proportion of losses realised (PLR). In Table 6, we present the results of our time-series analysis. Panel A contains the mean daily value of PGR; Panel B contains the mean daily value of PLR; Panel C contains the difference (PGR less PLR).

For the full sample period, both individuals and corporations prefer to cover short sales at a gain (i.e., following price declines), rather than at a loss. The results for individuals are robust across each of the five years that we analyse, though, in 1998 and 1999, corporations have no reliable preference for selling winning or losing short positions.

Cross-sectional analyses similar to those reported for long positions in Table 3 confirm the time-series results. The average corporation and the average individual prefer to sell winning, rather than losing, short positions. In addition, $71 \%$ of individuals sell winning short positions at a faster rate than losing short positions. However, only half of corporations do so (indicating the tendency to sell winning short positions is less systematic across corporations).

We also analyse the short-selling of individuals by gender. Men are somewhat more likely to sell short than women; $13 \%$ of men sell short, while $9 \%$ of women do so. Both men and women prefer to cover short positions for a gain rather than a loss.

\subsection{Market movements and the disposition effect}

The time-series of PGR and PLR during a five-year period when the Taiwan stock market experienced prolonged periods of significant appreciation and depreciation afford us the opportunity to analyse the relation between market movements and the propensity to sell winners and losers.

There are at least two reasons we expect to observe a relation between broad market movements and PGR (or PLR). First, it is likely that investors' reference points change as prices change. Throughout our analysis, we have considered the purchase price as the reference point for establishing gains and losses. However, following periods of appreciation in the market, investors are likely to view some stocks that are held for a gain as losers. For example, if the market has appreciated by $20 \%$ and investors hold a stock that has only appreciated by $10 \%$, some investors are likely to view the investment 
Table 6

Short positions: daily proportion of gains realised (PGR) and proportion of losses realised (PLR) by investor type and year

On each day, the proportion of gains realised is the total value of realised gains divided by the sum of realised gains and paper gains. There is an analogous calculation for losses. The table presents the mean daily value of the proportion of gains realised and the proportion of losses realised. Standard deviations (in parentheses) are calculated using a Newey-West correction for serial dependence.

\begin{tabular}{|c|c|c|c|}
\hline & Individual investors & Corporations & All investors \\
\hline \multicolumn{4}{|c|}{ Panel A: Mean of daily PGR } \\
\hline 1995 & 12.79 & 10.56 & 12.74 \\
\hline 1996 & 7.67 & 5.91 & 7.63 \\
\hline 1997 & 11.39 & 9.73 & 11.27 \\
\hline 1998 & 4.87 & 0.93 & 4.67 \\
\hline 1999 & 2.40 & 0.37 & 2.29 \\
\hline 1995-99 & 7.78 & 5.47 & 7.68 \\
\hline \multicolumn{4}{|c|}{ Panel B: Mean of daily PLR } \\
\hline 1995 & 7.89 & 5.65 & 7.85 \\
\hline 1996 & 3.64 & 1.81 & 3.60 \\
\hline 1997 & 3.23 & 1.29 & 3.16 \\
\hline 1998 & 2.57 & 1.12 & 2.51 \\
\hline 1999 & 1.67 & 0.55 & 1.61 \\
\hline $1995-99$ & 3.72 & 2.01 & 3.67 \\
\hline \multicolumn{4}{|c|}{ Panel C: Mean of difference (PGR-PLR) } \\
\hline \multirow[t]{2}{*}{1995} & $4.90^{* *}$ & $4.92^{* *}$ & $4.89^{* *}$ \\
\hline & $(0.83)$ & $(1.74)$ & $(0.84)$ \\
\hline \multirow[t]{2}{*}{1996} & $4.02^{* *}$ & $4.09^{* *}$ & $4.03^{* *}$ \\
\hline & $(0.66)$ & $(1.16)$ & $(0.67)$ \\
\hline \multirow[t]{2}{*}{1997} & $8.16^{* *}$ & $8.45^{* *}$ & $8.11^{* *}$ \\
\hline & (1.51) & $(3.40)$ & (1.54) \\
\hline \multirow[t]{2}{*}{1998} & $2.30^{* *}$ & -0.19 & $2.17^{* *}$ \\
\hline & $(0.54)$ & $(0.16)$ & $(0.52)$ \\
\hline \multirow[t]{2}{*}{1999} & $0.72^{* *}$ & -0.17 & $0.68^{* *}$ \\
\hline & $(0.22)$ & $(0.09)$ & $(0.22)$ \\
\hline \multirow[t]{2}{*}{ 1995-99 } & $4.06^{* *}$ & $3.47^{* *}$ & $4.01^{* *}$ \\
\hline & $(0.55)$ & $(0.96)$ & $(0.56)$ \\
\hline
\end{tabular}

as a loss, since the stock has underperformed the market. If this is the case, we would expect PGR to decrease following periods of appreciation, since we incorrectly classify some perceived losses as gains. Analogously, following periods of depreciation, we would expect PLR to increase, since we incorrectly classify some perceived gains as losses.

Second, heterogeneity in the tendency to sell winners and losers across investors will lead to a relation between broad market movements and PGR (or PLR). Our prior 
analyses reveal just such heterogeneity - corporations, individuals, and dealers prefer to sell winners rather than losers, while foreigners and domestic mutual funds do not prefer to do so. This heterogeneity will cause PGR and PLR to decrease following periods of appreciation and increase following periods of depreciation. ${ }^{10}$

To analyse these effects, we estimate a simple time-series regression using weekly values of PGR and PLR. Weekly values are obtained by summing paper gains, paper losses, realised gains, and realised losses across the week. We then estimate the following three time-series regressions:

$$
\begin{aligned}
& P G R_{t}=a+\sum_{i=1}^{8} b_{i} P G R_{t-i}+\sum_{i=1}^{8} c_{i} r_{t-i}+e_{t} \\
& P L R_{t}=a+\sum_{i=1}^{8} b_{i} P L R_{t-i}+\sum_{i=1}^{8} c_{i} r_{t-i}+e_{t} \\
& \left(\frac{P G R}{P L R}\right)_{t}=a+\sum_{i=1}^{8} b_{i}\left(\frac{P G R}{P L R}\right)_{t-i}+\sum_{i=1}^{8} c_{i} r_{t-i}+e_{t}
\end{aligned}
$$

where $a, b$, and $c$ are coefficient estimates, $r_{t}$ is the weekly return on the market, and $e_{t}$ is an error term. We include eight lags of the dependent variable, since empirically partial autocorrelations beyond eight lags are indistinguishable from zero.

The results of this analysis are presented in Table 7. Consider first the results for the ratio (PGR/PLR) for long positions (panel A). There is strong evidence that the propensity to sell winners, relative to losers, declines following strong market returns. The coefficient estimates on lagged market returns are generally negative - reliably so for lags of one to three weeks. Furthermore, we can comfortably reject the null hypothesis that the sum of the coefficients on lagged returns is equal to zero. When we separately analyse PGR and PLR, as anticipated, we find that lagged returns are negatively related to PGR. This is consistent with both changing reference points and heterogeneity in the willingness to sell winners. However, we find that PLR is positively related to past return (with the exception of lag length eight).

To test the robustness of these results, we also estimate analogous time-series regressions for PGR and PLR based on short positions (Table 7, Panel B). Note that the predicted relation between past returns and PGR (or PLR) is precisely the opposite of that

\footnotetext{
${ }^{10}$ To understand the effects of this heterogeneity, consider a simple example where the market consists of two investors - one who prefers to sell winners at twice the rate of losers and a second who sells winners and losers at an equal rate. For simplicity, assume both investors sell $10 \%$ of their portfolio. Following a period of appreciation, assume both investors hold portfolios comprised of $\$ 80$ of gains and $\$ 20$ of losses. The investors with no preference for selling winners or losers sells $\$ 8$ of gains and $\$ 2$ of losses, while the investor who prefers to sell winners at twice the rate of losers sells $\$ 8.89$ of gains and $\$ 1.11$ of losses. Across the two investors, the proportion of gains realised (PGR) is $(\$ 8+\$ 8.89) / \$ 160=0.106$, while the proportion of losses realised is $(\$ 2+\$ 1.11) / \$ 40=0.078$. Now consider a period following depreciation, where both investors hold portfolios comprised of $\$ 20$ of gains and $\$ 80$ of losses. The investor with no preference for selling winners and losers sells $\$ 2$ of gains and $\$ 8$ of losses, while the investor who prefers to sell winners at twice the rate of losers sells $\$ 3.33$ of gains and $\$ 6.67$ of losses. Thus, PGR is $(\$ 2+\$ 3.33) / \$ 40=0.133$ and PLR is $(\$ 8+\$ 6.67) / \$ 160=0.092$. Note that PGR and PLR are both lower following periods of appreciation.
} 


\section{Table 7}

Time-series relation of weekly market returns and proportion of gains realised (PGR), the proportion of losses realised (PLR), and the ratio of PGR to PLR: 1995-99

The dependent variable is alternately (1) the weekly proportion of gains realised, (2) the weekly proportion of losses realised (PLR), and (3) the ratio of PGR to PLR. Independent variables include eight weekly lags of the dependent variable and eight lags of weekly market returns $(\log$ returns $-r)$ :

$$
P G R_{t}=a+\sum_{i=1}^{8} b_{i} P G R_{t-i}+\sum_{i=1}^{8} c_{i} r_{t-i}+e_{i}
$$

There are analogous equations for $P L R$ and $P G R / P L R$. The sample period begins in the 20th week of 1995 and ends in the last week of 1999 (241 weekly observations). Test statistics are calculated using a Newey-West correction for serial dependence.

Dependent variable

\begin{tabular}{llllll}
\hline \multicolumn{2}{l}{ PGR/PLR } & PGR & \multicolumn{3}{c}{ PLR } \\
\hline Coef. & t-stat & Coef. & t-stat & Coef. & t-stat \\
\hline
\end{tabular}

Panel A: Regression results for long positions

\begin{tabular}{|c|c|c|c|c|c|c|}
\hline \multirow{2}{*}{$\begin{array}{l}\text { Intercept } \\
\text { Lag length: }\end{array}$} & 0.296 & $2.45^{* *}$ & 0.005 & $2.23^{* *}$ & 0.002 & $2.22^{* *}$ \\
\hline & \multicolumn{6}{|c|}{ Lagged dependent variable: } \\
\hline 1 & 0.575 & $5.61^{* * *}$ & 0.642 & $6.27^{* * *}$ & 0.896 & $8.81^{* * *}$ \\
\hline 2 & 0.237 & $2.43^{* *}$ & 0.055 & 0.50 & -0.248 & $-1.89^{*}$ \\
\hline 3 & 0.194 & $1.86^{*}$ & 0.279 & $2.46^{* *}$ & 0.335 & $2.75^{* * *}$ \\
\hline 4 & -0.269 & $-1.87^{*}$ & -0.122 & -0.88 & -0.107 & -0.97 \\
\hline 5 & 0.066 & 0.54 & -0.067 & -0.57 & -0.036 & -0.27 \\
\hline 6 & -0.001 & -0.01 & -0.008 & -0.09 & -0.030 & -0.39 \\
\hline 7 & -0.007 & -0.07 & 0.041 & 0.25 & 0.104 & 1.20 \\
\hline \multirow[t]{2}{*}{8} & 0.092 & 1.08 & 0.036 & 0.32 & -0.021 & -0.33 \\
\hline & \multicolumn{6}{|c|}{ Lagged market returns } \\
\hline 1 & -9.323 & $-3.13^{* * *}$ & -0.056 & -1.14 & 0.059 & $5.23^{* * *}$ \\
\hline 2 & -9.055 & $-4.74^{* * *}$ & -0.058 & $-1.94^{*}$ & -0.001 & -0.19 \\
\hline 3 & -4.270 & $-1.85^{*}$ & -0.055 & $-1.72^{*}$ & 0.014 & $2.01^{* *}$ \\
\hline 4 & -0.812 & -0.38 & -0.045 & -1.62 & -0.007 & -0.62 \\
\hline 5 & 1.353 & 0.44 & 0.049 & 1.32 & 0.003 & 0.38 \\
\hline 6 & -3.638 & -1.46 & -0.052 & $-2.14^{* *}$ & -0.006 & -0.73 \\
\hline 7 & -1.180 & -0.49 & -0.012 & -0.43 & 0.007 & 0.79 \\
\hline 8 & -0.921 & -0.42 & -0.033 & -1.07 & -0.014 & $-2.10^{* *}$ \\
\hline Adj. R-Sq. (\%) & 68.9 & & 61.2 & & 80.8 & \\
\hline Wald Test: $\sum_{i=1}^{8} c_{i}=0$ & $29.05^{* * *}$ & & $9.04^{* * *}$ & & $7.10^{* * *}$ & \\
\hline
\end{tabular}

for long positions, thus providing a natural test of the robustness of our results for long positions. Consistent with the results for long positions, we find that the propensity to sell winners declines following poor market returns for short positions, PGR is positively related to past market returns, and PLR is negatively related to past market returns. 
Table 7

Continued.

Dependent variable:

\begin{tabular}{llllll}
\hline \multicolumn{2}{l}{ PGR/PLR } & PGR & & \multicolumn{2}{l}{ PLR } \\
\hline Coef. & t-stat & Coef. & t-stat & Coef. & t-stat
\end{tabular}

Panel B: Regression results for short positions

\begin{tabular}{|c|c|c|c|c|c|c|}
\hline \multirow{2}{*}{$\begin{array}{l}\text { Intercept } \\
\text { Lag length: }\end{array}$} & 0.233 & 1.63 & 0.003 & 1.01 & 0.003 & $2.39^{* *}$ \\
\hline & \multicolumn{6}{|c|}{ Lagged dependent variable: } \\
\hline 1 & 0.600 & $6.99^{* * *}$ & 0.540 & $5.07^{* * *}$ & 0.647 & $6.67^{* * *}$ \\
\hline 2 & -0.129 & -1.11 & 0.094 & 0.85 & -0.008 & -0.07 \\
\hline 3 & 0.373 & $2.55^{* *}$ & 0.317 & $2.87^{* * *}$ & 0.237 & $2.58^{* *}$ \\
\hline 4 & -0.178 & -1.57 & 0.012 & 0.16 & -0.159 & -1.28 \\
\hline 5 & 0.064 & 0.61 & -0.115 & -1.17 & 0.136 & 1.35 \\
\hline 6 & 0.068 & 0.61 & 0.018 & 0.19 & -0.007 & -0.07 \\
\hline 7 & 0.135 & $1.72^{*}$ & 0.003 & 0.03 & 0.035 & 0.35 \\
\hline \multirow[t]{2}{*}{8} & -0.048 & -0.60 & 0.068 & 0.74 & 0.019 & 0.23 \\
\hline & \multicolumn{6}{|c|}{ Lagged market returns } \\
\hline 1 & 10.910 & $4.94^{* * *}$ & 0.282 & $3.16^{* * *}$ & -0.059 & $-2.12^{* *}$ \\
\hline 2 & 4.186 & $1.79^{*}$ & 0.129 & $2.30^{* *}$ & -0.025 & -1.25 \\
\hline 3 & 4.094 & $1.70^{*}$ & 0.034 & 0.56 & -0.051 & $-2.17^{* *}$ \\
\hline 4 & 2.982 & 1.46 & 0.095 & $1.94^{*}$ & 0.005 & 0.23 \\
\hline 5 & 3.009 & 1.21 & -0.020 & -0.37 & -0.006 & -0.38 \\
\hline 6 & 4.761 & $2.05^{* *}$ & 0.080 & 1.42 & -0.013 & -0.75 \\
\hline 7 & 2.172 & 1.07 & 0.019 & 0.32 & 0.015 & 0.98 \\
\hline 8 & -2.243 & -1.31 & -0.121 & $-2.23^{* *}$ & -0.032 & $-1.81^{*}$ \\
\hline Adj. R-Sq. (\%) & 66.9 & & 75.4 & & 83.5 & \\
\hline Wald Test: $\sum_{i=1}^{8} c_{i}=0$ & $30.57^{* * *}$ & & $12.27^{* * *}$ & & $8.73^{* * *}$ & \\
\hline
\end{tabular}

$* * *,{ }^{* *},{ }^{*}$ - significant at the 1,5 , and $10 \%$ level (two-tailed test)

In summary, there is strong evidence that the propensity to sell winners declines following periods of appreciation (or depreciation for short positions). Both heterogeneity in the willingness to sell winners across investors and changing reference points would yield this result. Neither explains why the proportion of losses realised (PLR) increases following periods of appreciation (or depreciation for short positions). One possible explanation - not tested here - is that as the market appreciates, many stock positions held for losses appreciate, though not to the break even point. Some investors may be satisfied getting out of a losing position at a better price than they could have gotten a week or two earlier.

\section{Discussion and Implications}

We have provided strong evidence that the typical and the aggregate investor prefer to sell winners rather than losers. In this section we discuss the possible implications of this finding for returns and volume. 


\subsection{Returns}

Grinblatt and Han (2002) and Weber and Zuckel (2002) develop models wherein some investors prefer to sell winners and hold losers. Disposition investors have higher demand for losing stocks than winning stocks, ceteris paribus. In these models, since the demand for stocks by other investors is not perfectly elastic, stocks underreact to public information and generate momentum in stock returns. Thus, the disposition effect is proposed as a potential explanation of the momentum profits documented by Jegadeesh and Titman (1993) and Rouwenhorst (1998). Grinblatt and Han (2002) and Goetzmann and Massa (2003) provide empirical support for the link between the disposition effect and momentum profits in the USA.

Given the strong tendency for Taiwanese investors to realise winners rather than losers, the Grinblatt-Han and the Weber-Zuckel models predict the presence of a strong momentum effect in Taiwan. To investigate this prediction, we construct momentum portfolios for Taiwan as in Jegadeesh and Titman (1993) for the period 1981-2002. In each month, stocks are sorted into quintiles based on their returns in the prior $k$ months (where $k=1,3$, or 6 ). The quintile with the highest returns during the formation period is labelled the winner portfolio, while the quintile with the lowest returns is labelled the loser portfolio. Portfolio returns are calculated assuming a holding period of $j$ months (where $j=1,3$, or 6 ). Portfolio returns are value-weighted, though the results are qualitatively similar when we equal weight returns.

The results of this analysis are presented in Table 8, Panel A. There are no reliable momentum profits in Taiwan. Our momentum results are consistent with those of Hong et al. (2003) and Hameed and Kusnadi (2002), who both find no evidence of momentum profits in Taiwan. Hameed and Kusnadi find no statistically significant momentum profits from 1981 to 1994 for Taiwan, Malayasia, Singapore, Hong Kong, South Korea, and Thailand. Thus a widespread and strong disposition effect in Taiwan is not sufficient to generate momentum in the cross-section of stock returns. This result casts doubt on Grinblatt and Han's contention that the disposition effect is the cause of momentum in the USA.

While we are sympathetic to the notion that the disposition effect may contribute to momentum profits, we conjecture that there is also an important countervailing effect the tendency for investors to be trend chasers who buy stocks with strong past returns. Using trade data from a discount broker and retail broker in the USA, Barber et al. (2006) document that, on average, investors prefer to buy stocks with strong past returns (see also Odean, 1999). If some investors prefer to sell winners, while some (perhaps the same) investors prefer to buy winners, the pricing implications of these two biases will depend on the relative sise of the two groups who exhibit them and the intensity of their preferences.

\subsection{Volume}

If the aggregate investor prefers to sell winners rather than losers, ceteris paribus, volume will almost certainly increase following periods of significant appreciation. When the majority of stocks are held for gains, the aggregate investor is more willing to sell. (Though the propensity to sell winners declines following periods of appreciation, this decrease is more than offset by the greater proportion of the market being held for gains.)

To investigate this conjecture, we estimate a simple vector autoregression using weekly ( $\log$ ) market returns and weekly turnover for the TSE for the period January 1981 to May 


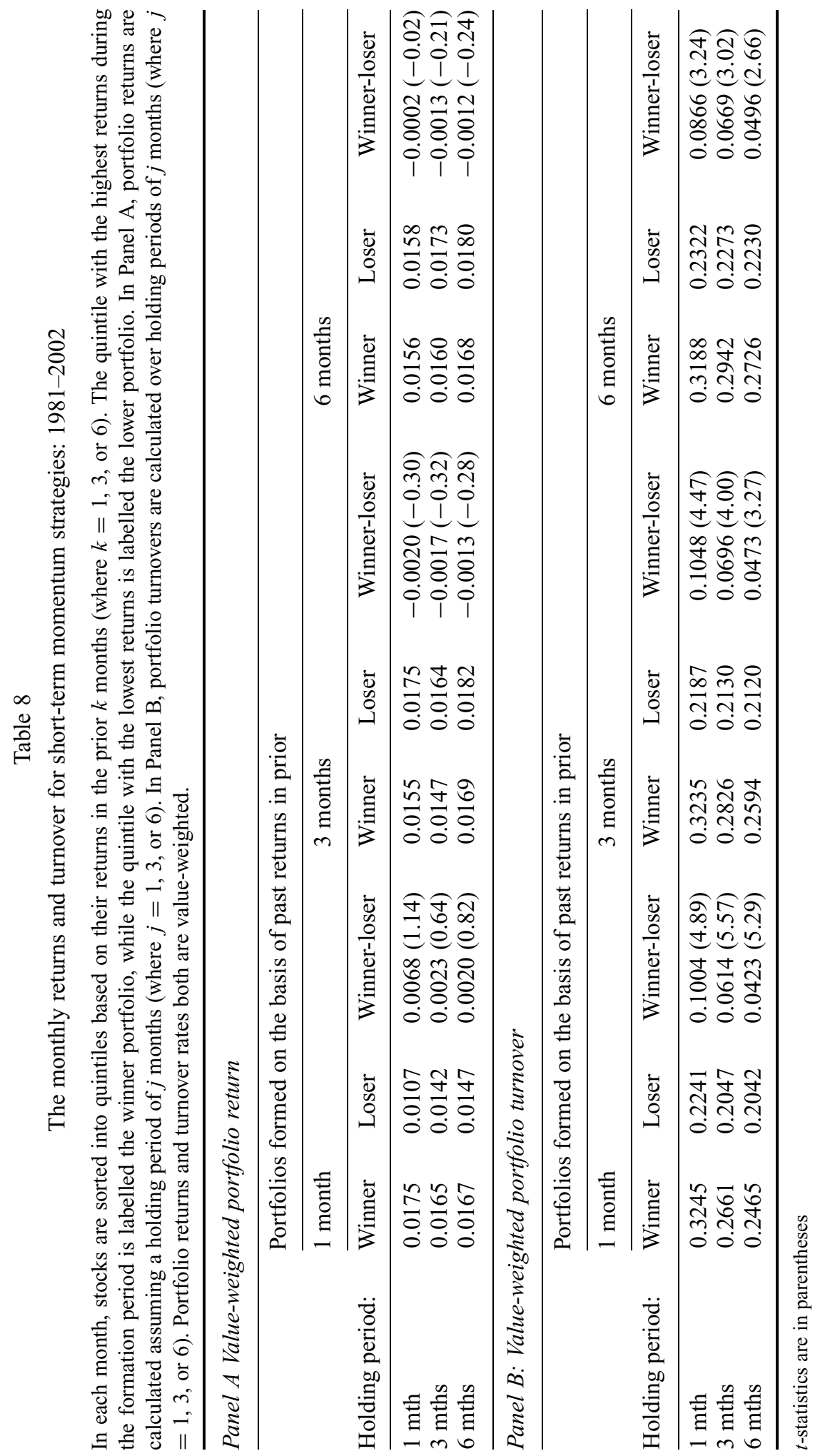




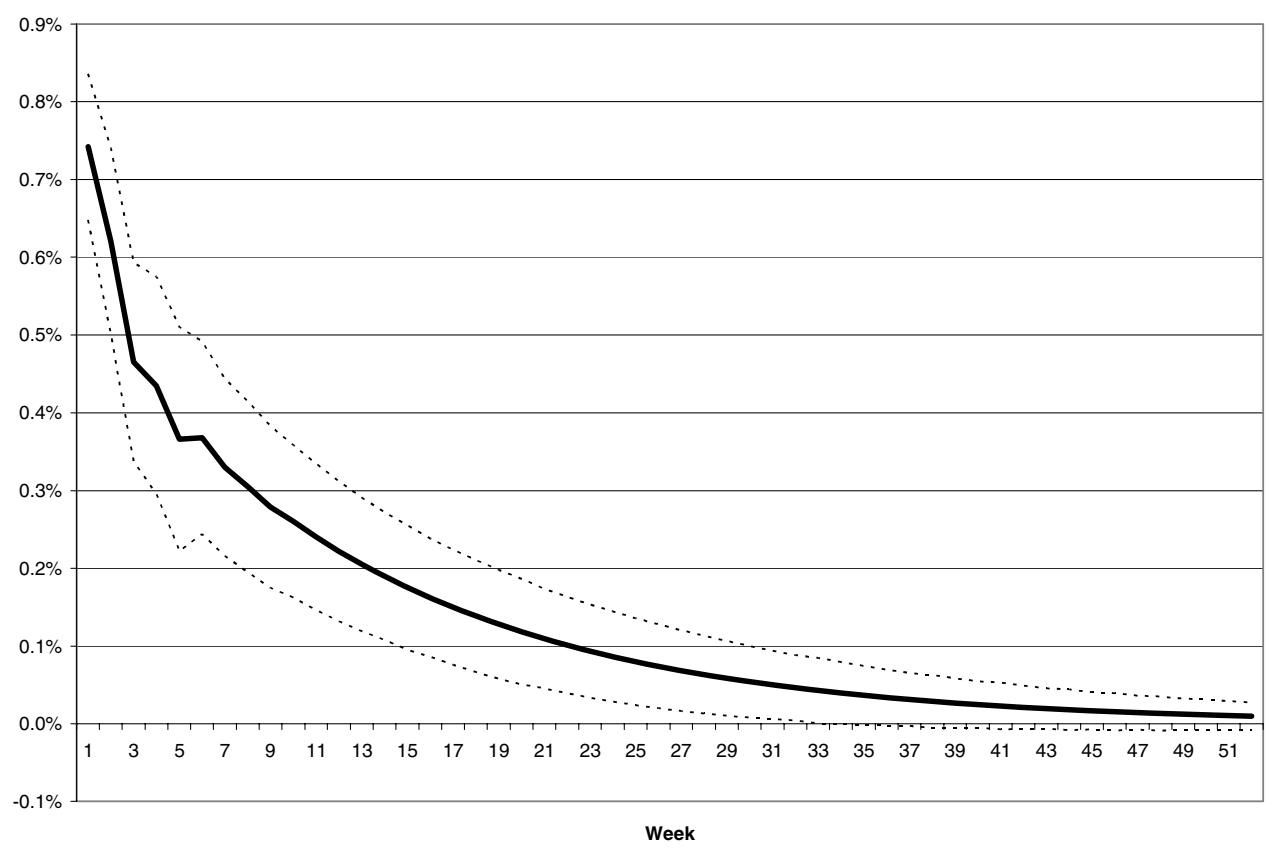

Fig. 3. Generalised impulse response function of weekly turnover to one standard error shock to $(\log )$ market return

The impulse response function is estimated using a vector autoregression of weekly turnover and weekly (log) market returns with four lags. The generalised impulse response function is calculated as described in Pesaran and Shin (1998).

2003. Weekly turnover is defined as total dollar volume divided by beginning-of-week market capitalisation. Mean weekly turnover during this period is $4.7 \%$ (244\% annual turnover), while median turnover is $4 \%$ (208\% annual turnover).

Not surprisingly, preliminary analyses reveal strong time-series dependence in turnover, but weak time-series dependence in market returns. We estimate a VAR with four lags of market returns and four lags of turnover. ${ }^{11}$ Granger causality tests from this simple VAR indicate innovations to market returns increase turnover $(p<0.01)$. In Figure 3, we present the generalised impulse response of a one standard error shock to returns on turnover. The effect of returns on turnover is immediate and persists for almost one year. The short-term effect (roughly $0.7 \%$ ) is also economically large approximately $15 \%$ of the unconditional mean of weekly turnover. When we decompose the variance of turnover into that attributable to innovations in market returns and innovations in turnover, between 20 and $30 \%$ of the variation in turnover is attributable to innovations in market returns. In summary, there is strong support for the conjecture that innovations to market returns increase turnover.

Our VAR results are qualitatively similar to those of Statman et al. (2006) for the US market; they document that innovations to market returns increase turnover in the US market. Though they recognise the potential importance of the disposition effect, they

\footnotetext{
${ }^{11}$ We choose four lags based on the Schwartz lag length criterion. Our results are not sensitive to the choice of lag length.
} 
emphasise self-attribution bias as the primary factor underlying this relation. Investors with a self-attribution bias attribute their successes to their own abilities and failures to exogenous factors. Thus, when the market performs well, investors who attribute their strong returns to their own abilities are likely to become overconfident and, thus, trade more (Gervais and Odean, 2001).

We are unable to differentiate these competing explanations for the observed relation between market returns and marketwide turnover. However, the explanations yield somewhat different predictions for the cross-section of turnover. The disposition effect predicts that turnover will be greatest for stocks with the strongest recent returns, while self-attribution driven turnover is likely to be less stock specific. To investigate this possibility, we calculate turnover for each of the momentum portfolios constructed in the previous section. As reported in Table 8, we find that the quintile of stocks with the greatest recent returns experiences much higher subsequent turnover than the quintile with the lowest recent returns. This result is consistent with the disposition effect. However, it may also be caused, in part, by buyer driven trades chasing good recent performance.

\section{Conclusion}

We analyse all trades made on the Taiwan Stock Exchange between 1995 and 1999 and provide strong evidence that, in aggregate and individually, investors have a disposition effect; that is, investors prefer to sell winners and hold losers. The disposition effect exists for both long and short positions, for both men and women (to roughly the same degree), and tends to decline following periods of market appreciation.

Eighty-five percent of all Taiwanese investors sell winners at a faster rate than losers. The only two investor types that do not do so, mutual funds and foreign investors, account for less than $5 \%$ of all trades. Clearly a bias that is so widespread and shared by some, though not all, institutional investors has the potential to affect asset prices and trading volume. Some researchers have proposed that the disposition effect might explain the profitability of momentum strategies. However, we find little evidence of momentum profits in Taiwan, despite the strong marketwide preference for selling winners rather than losers. Possibly, the tendency of Taiwanese investors to chase performance offsets any pricing effects of their preference to sell winners. The relationship between returns and subsequent trading volume, both for the market and at the individual stock level, is completely consistent with the disposition effect. Following periods of price appreciation, the willingness to sell increases. Our empirical analyses indicate marketwide turnover increases following periods of appreciation. In addition, stocks with strong recent returns experience higher subsequent turnover than stocks with poor recent returns.

We live in a world where decisions - even those for which chance plays a large role - are judged on outcomes. Most investors who buy and sell individual securities have little or no ability to distinguish future winners and losers. They do, however, have the ability to put off the day of reckoning. The typical and the aggregate investor postpone selling losing investments because they, like the rest of us, hate to admit their mistakes. 


\section{Appendix}

Details of the calculation of paper gains, paper losses, realised gains, and realised losses

The daily positions of each trader are built up based on her trading activity. Consider the case of long positions. The counting of paper gains and paper losses begins on the day following the purchase of the security. (If the first trade in a stock is a sale, the sale is ignored.) On days with no sales, paper positions are recorded as follows: if the average purchase price of the shares is less than the low for the day, a paper gain is recorded. If the average purchase price is greater than the high for the day, a paper loss is recorded. If the average purchase price is between the high and low for the day, the position is assigned to an indeterminate category. The value of the paper position is recorded as the shares held times the prior day's closing price. If a position is sold on a day, the sale is recorded as a realised gain if the sales price exceeds the average purchase price, a realised loss if the sales price is less than the average purchase price, and indeterminate if the sales price and average purchase price are equal. On days when investors sell part, but not all, of their outstanding shares (i.e., a partial sale), we record both paper and realised values. The shares sold are recorded as a realised gain, realised loss, or realised indeterminate in the same manner as complete sales. The unsold portion of the position is recorded as a paper gain, paper loss, or paper indeterminate by comparing the average purchase price to the sales price of shares sold. Examples of these calculations for one stock are presented in Table A1.

We define day trading as the purchase and sale of the same stock on the same day. If a stock is bought and sold on the same day, we net out the trading activity for the day and treat the net balance as one purchase or one sale. For example, if an investor bought 2000 and sold 1000 shares of a stock on the same day, we would treat this as a purchase of 1000 shares. Conversely, if the investor bought 1000 shares and sold 2000 shares, we would treat this as a sale of 1000 shares. In the majority of cases $(64 \%)$, day trading results in no net balance.

Short sales and short purchases (i.e., purchases that cover short positions) are coded as such in the trade data. Thus, the calculation of paper and realised values for short positions is completely analogous to that for long positions. Occasionally, we observe short sales when an investor has an outstanding long position in the same stock. In these cases, we treat the short sale as a regular sale, rather than tracking a separate long and short position for the same stock. Similarly, we also observe long purchases when an investor has an outstanding short position in the same stock. In these cases, we treat the long purchase as a short purchase, rather than tracking a separate long and short position for the same stock.

\section{References}

Barber, B. M., Lee, Y.-T., Liu, Y.-J. and Odean, T., 'Do individual day traders make money? Evidence from Taiwan', SSRN Working Paper, http://ssrn.com/abstract=529063, 2005.

Barber, B. M. and Odean, T., 'The courage of misguided convictions: the trading behavior of individual investors', Financial Analysts Journal, Vol. 55, No. 6, 1999, pp. 41-55.

Barber, B. M. and Odean, T., 'Boys will be boys: gender, overconfidence, and common stock investment', Quarterly Journal of Economics, Vol. 116, No. 1, 2001, pp. 261-92. 


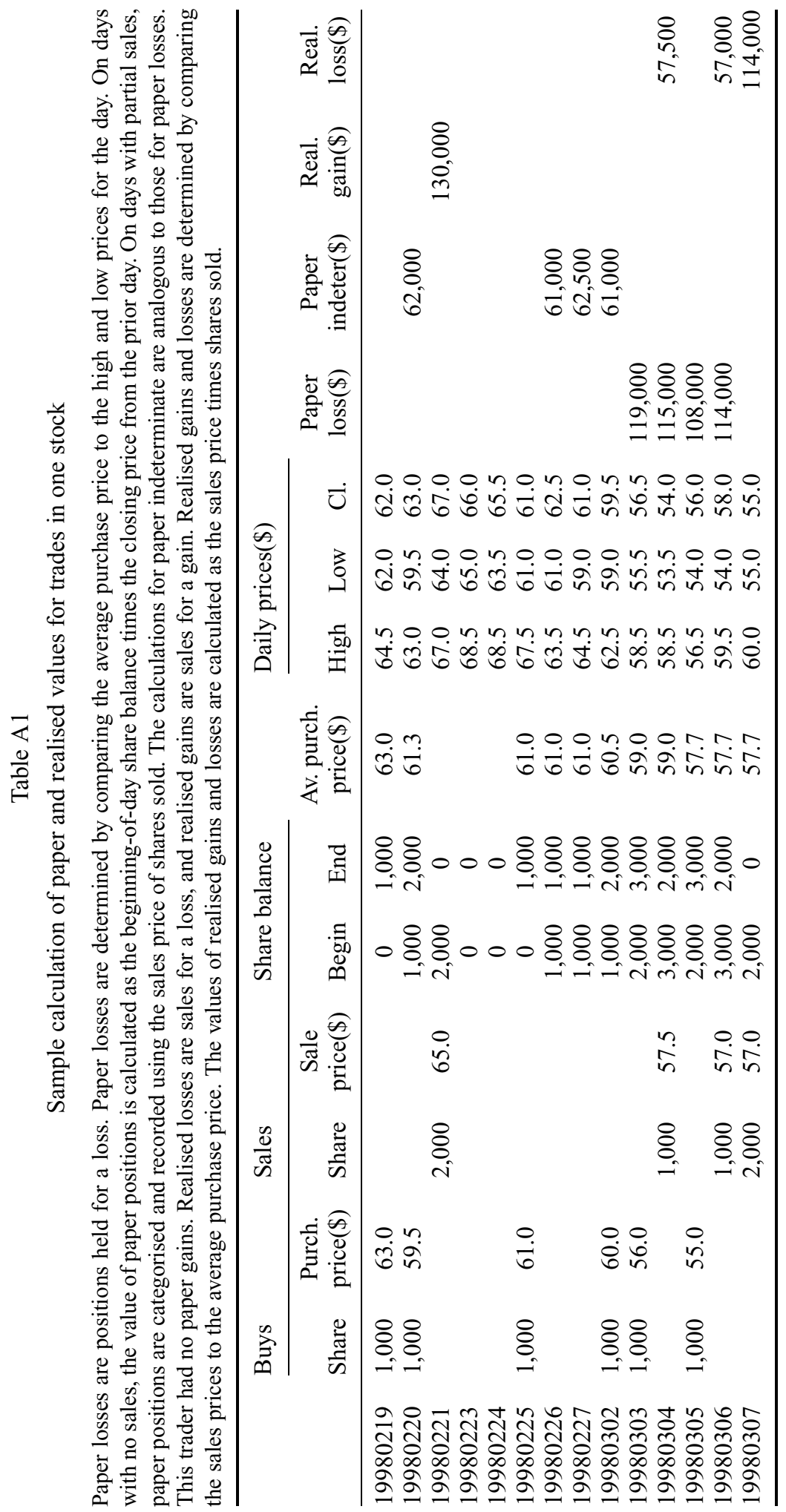


Barber, B. M., Odean, T. and Strahilevitz, M., 'Once burned, twice shy: how naïve learning and couterfactuals affect the repurchase of stocks previously sold', SSRN Working Paper, http://ssrn.com/abstract=611267, 2006.

Barber, B. M., Odean, T. and Zhu, N., 'Systematic noise', SSRN Working Paper: http://ssrn.com/abstract=474481, 2006.

Coval, J. D. and Shumway, T., 'Do behavioral biases affect prices?', Journal of Finance, Vol. 61, No. 1, 2005, pp. 1-34.

Dhar, R. and Zhu, N., 'Up close and personal: an individual level analysis of the disposition effect', Management Science, forthcoming 2006.

Genesove, D. and Mayer, C., 'Nominal loss aversion and seller behavior: evidence from the housing market', Quarterly Journal of Economics, Vol. 116, No. 4, 2001, pp. 1233-60.

Gervais, S. and Odean, T., 'Learning to be overconfident', Review of Financial Studies, Vol. 14, No. 1, 2001, pp. 1-27.

Goetzmann, W. N. and Massa, M., 'Disposition matters: volume, volatility and price impact of a behavioral bias', Yale ICF Working Paper No. 03-01. Available at SSRN: http://ssrn.com/abstract=377043, 2003

Grinblatt, M. and Han, B., 2002, 'The disposition effect and momentum', NBER Working Paper No. W8734. Available at SSRN: http://ssrn.com/abstract=298258, 2003.

Grinblatt, M. and Keloharju, M., 'What makes investors trade?', Journal of Finance, Vol. 56, 2001, pp. 589-616.

Hameed, A. and Kusnadi, Y., 'Momentum strategies: evidence from Pacific Basin stock markets', Journal of Financial Research, Vol. 25, No. 3, 2002, pp. 383-97.

Heath, C., Huddart, S. and Lang, M., 'Psychological factors and security option exercise', Quarterly Journal of Economics, Vol. 114, No. 2, 1999, pp. 601-27.

Hong, D., Lee, C. M. C. and Swaminathan, B., 'Earnings momentum in international markets', Cornell Working Paper (2003).

Jackson, A., 'The aggregate behaviour of individual investors', SSRN Working Paper, http://ssrn.com/abstract=536942, 2004.

Jegadeesh, N. and Titman, S., 'Returns to buying winners and selling losers: implications for stock market efficiency', Journal of Finance, Vol. 48, 1993, pp. 65-91.

Kahneman, D. and Tversky, A., 'Prospect theory: an analysis of decision under risk', Econometrica, Vol. 46, 1979, pp. 171-85.

Locke, P. and Mann, S., 'Do professional traders exhibit loss realisation aversion?', SSRN Working Paper, http://ssrn.com/abstract=251942, 2001.

Odean, T., 'Are investors reluctant to realize their losses?', Journal of Finance, Vol. 53, 1998, pp. 1775-98.

Odean, T., 'Do investors trade too much?', American Economic Review, Vol. 89, 1999, pp. 1279-98.

Rouwenhorst, K. G., 'International momentum strategies', Journal of Finance, Vol. 53, No. 1, 1998, pp. 267-84.

Shapira, Z. and Venezia, I., 'Patterns of behavior of professionally managed and independent investors', Journal of Banking and Finance, Vol. 25, 2001, pp. 1573-87.

Shefrin, H. and Statman, M., 'The disposition to sell winners too early and ride losers too long: theory and evidence', Journal of Finance, Vol. 40, 1985, pp. 777-90.

Statman, M., Thorley, S. and Vorkink, K., 'Investor overconfidence and trading volume', Review of Financial Studies, Vol. 19, No. 4, 2006, pp. 1531-65.

Thaler, R., 'Mental accounting and consumer choice', Marketing Science, Vol. 3, 1985, pp. 199-214.

Weber, M. and Zuchel, H., 'The disposition effect and momentum', SFB 504 discussion paper 01-26, 2002. 